\title{
Administrative Law, Judicial Deference, and the Charter
}

\author{
Matthew Lewans ${ }^{\star}$
}

\section{Introduction}

The doctrine of judicial deference has been a touchstone in Canadian administrative law for thirty-five years. Put simply, the doctrine recognizes that administrative officials have legitimate authority to interpret the law, which means that judicial review is warranted only if an administrative decision is demonstrably unfair or unreasonable. ${ }^{1}$ While the tide of deference has ebbed and flowed over this period, ${ }^{2}$ most administrative decisions these days are assessed according to a standard of reasonableness instead of correctness. ${ }^{3}$ However, until very recently the Supreme Court has refused to defer to administrative decisions concerning constitutional values, so that any time an administrative official ventured an opinion on the Canadian Charter of Rights and Freedoms the decision was relatively prone to judicial review.

This changed in Doré v Barreau du Québec. ${ }^{4}$ The issue in Doré concerned a professional disciplinary decision - the Disciplinary Council of the Barreau du Quebec suspended Gilles Dorés license for 21 days because he sent a private letter to a superior court judge, chastising the judge for unprofessional conduct in the courtroom. Even though the Council's decision limited Dorés Charter right to freedom of expression, the Supreme Court held that the decision should be reviewed on the administrative law standard of reasonableness rather than a de novo judicial application of the Oakes test. This decision is remarkable, because it signals an extension of judicial deference, which is rooted in the realm of Canadian administrative law, to the Charter domain. Furthermore, because the Court does not limit its holding on the facts presented by the Doré case, this posture of deference extends to all administrative decisions. The basis for the Court's conclusion in Doré invokes the traditional rationale for deference: that administrative decision-makers, by virtue of their experience and field sensitivity, have a unique and valuable perspective regarding constitutional values in a specific regulatory context.

In this paper, I will attempt to situate Doré within the Court's earlier case law by examining the interplay between administrative law and Charter jurisprudence and the interrelationship between constitutionalism, courts, and the administrative state. Put simply, I will argue that Doré represents a fundamental shift away from formal constitutionalism (which gives Parliament exclusive law-making power and courts exclusive interpretive authority over the law) towards democratic constitutionalism (in which the lines separating the legislative, adjudicative, and administrative functions are blurred and administrative officials share responsibility for interpreting the law). Thus, Doré requires judges to relinquish their claim of being exclusive arbiters of the "correct" interpretation of the Charter and instead review administrative decisions regarding Charter values according to a "reasonableness" standard. I will conclude by argu- 
ing that, while the Court's decision in Doré is a welcome development which has the potential to stimulate a more democratic discourse regarding constitutional rights, the full potential of that discourse cannot be realized in the absence of further doctrinal reforms.

\section{From parliamentary sovereignty to democratic constitutionalism}

While the notion that judges should defer to administrative judgment is well established, it remains controversial because it conflicts with traditional assumptions regarding the judiciary's constitutional role. Until 1978, the orthodox view was that the Canadian constitutional order was premised on a formal separation of powers whereby Parliament and the provincial legislatures wielded supreme legislative power within their respective spheres, superior courts had the final word on interpreting the law, and administrative officials were merely responsible for implementing the law enacted by legislatures and interpreted by judges. This conception of the separation of powers is formal, because it assumes that the purpose of judicial review is to ensure that each institution is confined to its constitutional role, and that this can be accomplished by divining the abstract nature of the power being exercised instead of scrutinizing the substantive merits of an administrative decision. ${ }^{5}$ Thus, if reviewing judges deemed that a delegated power was "judicial" in nature or involved a "jurisdictional" question of law, they could intervene if they disagreed with the outcome; but if they deemed that the power was "administrative" or involved a "non-jurisdictional" question, they assumed that the decision was beyond judicial scrutiny. ${ }^{6}$ The problem was that these abstract distinctions were so pliable that judges could expand or retract the scope of judicial review by manipulating the notion of legislative intent without providing a more explicit, principled justification for judicial review or (alternatively) judicial restraint under the circumstances.

These assumptions were revised in a series of landmark decisions rendered by the Laskin Court in the late 1970s. Under this new model, which was formulated in Nicholson $v$ Haldimand-Norfolk (Regional) Police Commissioners ${ }^{7}$ and CUPE, ${ }^{8}$ the separation of powers was complicated by the recognition that administrative officials have a legitimate role to play in interpreting the law. Thus, the focus of judicial review shifted away from the formal separation of powers rationale toward ensuring that administrative decisions should abide by fundamental legal values like procedural fairness and substantive reasonableness. So instead of operating on the assumption that an omniscient legislature had explicitly or implicitly determined the parameters of administrative jurisdiction ab initio, Dickson J in CUPE recognized that enabling legislation often "bristles with ambiguities" which meant that judges "should not be alert to brand as jurisdictional, and therefore subject to broader curial review, that which may be doubtfully so." ${ }^{10}$ And instead of assuming that judges are entitled to the final word on legal interpretation, he recognized that "a board is called upon not only to find facts and decide questions of law, but also to exercise its understanding of the body of jurisprudence that has developed around the collective bargaining system....and its labour relations sense acquired from accumulated experience." ${ }^{11}$ In doing so, the Court took the position that administrative officials should be considered co-ordinate partners in interpreting and developing the law.

But despite this concession of interpretive power to administrative officials, neither CUPE nor Nicholson recommend judicial quiescence. ${ }^{12}$ While Dickson J articulated cogent reasons for respecting administrative decisions in CUPE, based on the democratic credentials and expertise of the public service labour relations board, he nevertheless held that a reviewing court should intervene only if a decision "cannot be rationally supported by the relevant legislation."13 This line of thinking culminated in Baker $v$ Canada and Dunsmuir $v$ New Brunswick, two cases in which the Court elaborated the purpose of reasonableness review. In Baker, the Court noted that administrative authority "must be exercised in accordance with the boundaries imposed in the statute, the principles of the rule of law, the principles of administrative law, the fundamental values of Canadian society, and the prin- 
ciples of the Charter". ${ }^{14}$ In Dunsmuir, the Court noted that "reasonableness is concerned mostly with the existence of justification, transparency and intelligibility within the decision-making process." 15 These passages illustrate that even in situations where judicial deference is warranted, judges have an important role to play in ensuring that administrative decisions are adequately justified in light of relevant legal principles, including constitutional principles.

Similarly, in Nicholson the Court famously held that the claimant was entitled to a hearing even though the enabling legislation was silent with respect to procedural entitlements for constables with less than eighteen months service. In Laskin CJ's view, the default assumption was that Nicholson should be treated fairly by officials wielding statutory power, especially in light of the severe consequences which flowed from the decision to terminate his employment. In later cases, the Court emphasized that this general doctrine of fairness did not mean that all administrative processes had to conform to the trialtype hearings employed by common law courts. Rather, it articulated a doctrine of fairness which was compatible with the notion of judicial deference toward administrative judgment. Hence, even though Dickson J held that the board of governors owed a common law duty of fairness in Kane $v$ Board of Governors of the University of British Columbia, he also recognized that the board was "free, within reason, to determine its own procedures, which will vary with the nature of the inquiry and the circumstances of the case." 16

Taken together, the Nicholson and CUPE lines of authority signal a fundamental shift in Canadian constitutionalism, which has important ramifications for judicial review in the administrative law context. The pre-CUPE model assumed that the purpose of judicial review was to preserve constitutional hierarchy anchored by Parliamentary sovereignty over law-making and judicial supremacy over legal interpretation; the post-CUPE model is premised on a more complex, democratic conception of Canadian constitutionalism, in which the line between legislative, adjudicative, and executive functions is blurred and institutions traditionally regarded as "inferior courts" now play a significant role both in interpreting enabling legislation and fundamental values across a broad range of government policy.

\section{Adminsitrative officials and the Charter}

While judicial review of most types of administrative decisions has generally shifted towards reasonableness review, the formal separation of powers argument still crops up from time to time. It persists most noticeably in cases where administrative officials address human rights issues, as in judicial review of human rights tribunal decisions. Even though the doctrine of deference has become well entrenched in fields such as labour relations, there is still a line of case authority which asserts that human rights tribunals decisions should be subjected to correctness review because " $\mathrm{t}$ ]he superior expertise of a human rights tribunal relates to fact-finding" and "does not extend to general questions of law". ${ }^{17}$ Despite sustained academic criticism of this proposition, recent case law from the Supreme Court of Canada suggests that even when a standard of reasonableness is employed in cases concerning human rights tribunals, judges often still prefer heavy-handed oversight. ${ }^{18}$

When it comes to judicial review of administrative decisions involving the Charter, the Supreme Court's jurisprudence reflects the fundamental tension between the formal conception of the separation of powers and democratic constitutionalism. In Slaight Communications $v$ Davidson, one of the first Supreme Court decisions which addressed judicial review of administrative decisions affecting Charter rights, the conflict between the opinions written by Dickson CJ and Lamer J is symptomatic of this deeper conflict. ${ }^{19}$ The case concerned the constitutionality of a labour adjudicator's decision, which imposed both positive obligations and negative constraints on the former employer's future conduct. The positive aspects of the adjudicator's decision required the employer to provide a letter of reference with content specified and vet- 
ted by the adjudicator; the negative portion of the award restrained the employer from communicating with potential employers. The purpose of the decision was to prevent the employer from compounding the damage caused by an unjust dismissal by spreading falsehoods about the former employee's past job performance. The employer challenged the adjudicator's decision, arguing that it was both unreasonable and infringed its freedom of expression under the Charter.

Both Dickson CJ, who wrote the majority opinion, and Lamer J agreed that the adjudicator's remedial discretion was bound by the Charter because any public official "exercising delegated powers does not have the power to make an order that would result in an infringement of the Charter." ${ }^{20}$ But they disagreed about whether the adjudicator's decision was reasonable or, alternatively, justifiable under $\mathrm{s} 1$ of the Charter. Lamer J concluded that the negative portion of the order, which constrained future communications with potential employers, amounted to a jurisdictional error. ${ }^{21}$ Even though the Canada Labour Code gave the adjudicator authority to award monetary compensation, reinstatement or "any other like thing that it is equitable to require the employer to do",22 Lamer J thought the negative portion of the order was "wholly unreasonable" because it compelled Slaight's former boss to bite his tongue when responding to subsequent inquiries from other potential employers. ${ }^{23}$

With respect to the positive portion of the award, which required the employer to write a reference letter, Lamer J considered whether it infringed the employer's freedom of expression under the Charter. But in scrutinizing the constitutionality of the adjudicator's decision, Lamer J held that the legality of the adjudicator's decision should be assessed by engaging in a de novo application of the Oakes test, saying: ${ }^{24}$

To determine whether this limitation is reasonable and can be demonstrably justified in a free and democratic society... one must examine whether the use made of the discretion has the effect of keeping the limitation within reasonable limits that can be demonstrably justified in a free and democratic society. If the answer is yes, we must conclude that the adjudicator had the power to make such an order since he was authorized to make an order reasonably and justifiably limiting a right or freedom mentioned in the Charter. If on the contrary the answer is no, then one has to conclude that the adjudicator exceeded his jurisdiction since Parliament has not delegated to him a power to infringe the Charter. If he has exceeded his jurisdiction, his decision is of no force or effect.

The important point is that, in Lamer J's view, the constitutional limitations on the adjudicator were determined by the Court's independent assessment about what was demonstrably justifiable under s 1 of the Charter. Only after Lamer J concluded that (1) the objective of the adjudicator's award was sufficiently important, (2) the award was rationally connected to that objective, and (3) the award minimally impaired the employer's freedom of expression, did he conclude that the adjudicator "acted within his jurisdiction". ${ }^{25}$

By contrast, Dickson CJ's approach was more circumspect, stating that " $[\mathrm{t}]$ he precise relationship between the traditional standard... of patent unreasonableness and the new constitutional standard of review will be worked out in future cases." ${ }^{26}$ His only comment was that reasonableness review "should not impose a more onerous standard upon government than would Charter review" ${ }^{27}$ He then considered how the context of the dispute shaped the adjudicator's rationale, noting that "the adjudicator's remedy in this case was a legislatively-sanctioned attempt to remedy the unequal balance of power that normally exists between an employer and employee." 28 Given this context, he warned that judges should "avoid constitutionalizing inequalities of power in the workplace", suggesting that the order should be upheld "[a]s long as the proportionality test is met." ${ }^{29}$ In this respect, he emphasized that "the measures adopted by the adjudicator cannot be said to have done more than to have enhanced, as opposed to having ensured, the changes of the respondent finding a job." ${ }^{30}$ While Dickson CJ did not allude to the notion of deference in his opinion, his rationale resonates with the idea that judges should exercise a degree of restraint 
when reviewing administrative decisions rooted in a particular regulatory context and supported by acceptable reasons.

However, in future cases the Court leaned towards Lamer J's more restrictive approach, especially in cases concerning whether administrative officials have the power to apply the Charter to their own enabling legislation. The foundation for judicial review of these types of administrative decisions was laid out in a trilogy of cases from the early 1990s: Douglas/Kwantlen Faculty Association v Douglas College, Cuddy Chicks Ltd v Ontario (Labour Relations Board), and Tétrault-Gadoury $v$ Canada (EIC). ${ }^{31}$ The majority opinions in these cases, all written by LaForest J, establish the following propositions. First, LaForest J held that the power of administrative officials to apply the Charter does not flow directly from s 52 of the Constitution Act, 1982 , but is contingent upon whether the legislature has expressly or implicitly delegated the power to determine questions of law. ${ }^{32}$ Second, any administrative decision which implicates the Charter is subject to judicial review on a correctness standard, which means that judges should not defer to administrative decisions regarding Charter claims. ${ }^{33}$ Finally, the Court only addressed whether an administrative tribunal could refuse to apply a provision of its enabling legislation under s 52, leaving open the question of whether it was a "court of competent jurisdiction" which had access to the remedial powers mentioned in s 24 of the Charter. ${ }^{34}$ Thus, even though LaForest J recognized that there were "clear advantages" to enabling administrative officials to apply the Charter - advantages having to do with making Charter rights accessible, efficient and contextually sensitive - administrative jurisprudence regarding the Charter had generally been tightly circumscribed and vulnerable to judicial review. ${ }^{35}$

By contrast, Wilson J, who wrote concurring opinions in all three cases, suggested that the ability to apply the Charter was not contingent on legislative intent: "[ $t$ ]he absence of legislative authority to deal with the Charter issue in the governing statute is not, in my view, necessarily determinative of a tribunal's jurisdiction, since the authority and obligation to apply the law may be grounded elsewhere." ${ }^{36}$ Furthermore, she noted that "it may be necessary to proceed to s. 24(1) of the Charter and decide whether... the tribunal is a court of competent jurisdiction to decide a Charter issue arising in the context of the relief claimed." ${ }^{37}$

While these differences were somewhat muted in the trilogy, they were magnified in Cooper $v$ Canada, a case which split opinion on the Court in dramatic fashion. ${ }^{38}$ In that case, a group of airline pilots alleged that the compulsory retirement provisions in their collective agreement were discriminatory, but in order to succeed they had to confront s 15(c) of the Canadian Human Rights Act, which stated that "[i]t is not a discriminatory practice if... an individual's employment is terminated because the individual has reached the normal age of retirement". ${ }^{39}$ The claimants argued that this provision of the Human Rights Act infringed their right to equality under s 15 of the Charter. When the Commission refused to refer the complaint to the tribunal, the claimants asked the Federal Court to quash the decision and direct the Commission to appoint a tribunal of inquiry.

The majority opinion, again written by LaForest J, reiterated the positions taken in the trilogy. But this time, he emphasized that the trilogy had established "that no administrative tribunal has an independent source of jurisdiction pursuant to s 52(1) of the Constitution Act, 1982", which meant that the essential question was whether Parliament had expressly or implicitly delegated the power to determine questions of law to the Commission. ${ }^{40}$ Since, in his view, there was no explicit provision granting this power, he proceeded to consider whether this intent could be implied based on a consideration of "the composition and structure of the tribunal, the procedure before the tribunal, the appeal route from the tribunal and the expertise of the tribunal." ${ }^{41}$ On all counts, LaForest J concluded that Parliament did not intend for the Commission to determine questions of law, which meant that the Commission could not consider whether the provision in its enabling legislation was unconstitutional. In his view, the Commission's role 
was "administrative", not "adjudicative", which meant that its role was limited merely to applying the enabling legislation instead of considering broader issues concerning its constitutionality. ${ }^{42}$ Moreover, he suggested that the Commission was ill-suited to consider constitutional questions, because the complaint referral process was limited to a paper inquiry, was not bound by the traditional rules of evidence, and the Commission's expertise was limited merely to findings of fact. On this last point, LaForest J invoked his opinion in Mossop, a case in which he had stated that judges should not defer to human rights tribunal decisions because the tribunal's expertise "does not extend to general questions of law". ${ }^{43}$

Lamer CJ, who wrote a concurring opinion, opposed the idea that administrative officials could consider the constitutionality of their own enabling legislation. In his view, the separation of powers is "[o]ne of the defining features of the Canadian Constitution", which entails "that certain functions be exclusively exercised by judicial bodies." 44 While he did acknowledge "that judicial functions, including the interpretation of law, may be vested in non-judicial bodies", ${ }^{45}$ his rationale relies upon a formalist conception of the separation of powers. If administrative officials could assess the constitutionality of enabling legislation, it would upset the hierarchical relationship between a democratically elected legislature and the executive (on the one hand) ${ }^{46}$ and the exclusive jurisdiction of superior courts to interpret the Constitution (on the other). ${ }^{47} \mathrm{On}$ this latter point, Lamer CJ stated that the power to interpret the Charter was the exclusive domain of courts, because "only courts have the requisite independence to be entrusted with the constitutional scrutiny of legislation." 48

By contrast, the vigorous dissenting opinion written by McLachlin J advocated a more democratic understanding of Canadian constitutionalism. She asserted that "the majority approach depreciates the language of s 52 of the Constitution Act, 1982, makes it more difficult for the Human Rights Commission to fulfil its mandate, and places burdens on the victims of discrimination in their fight for equality". ${ }^{49}$ In her view, any time an administrative official exercises legal authority, he or she is obliged to consider how fundamental legal values, including the Charter, affects his or her legal mandate. In this respect, she noted that: ${ }^{50}$

\begin{abstract}
The Charter is not some holy grail which only judicial initiates of the superior courts may touch. The Charter belongs to the people. All law and law-makers that touch the people must conform to it. Tribunals and commissions charged with deciding legal issues are no exception. Many more citizens have their rights determined by these tribunals than by the courts. If the Charter is to be meaningful to ordinary people, then it must find its expression in the decisions of these tribunals. If Parliament makes it clear that a particular tribunal can decide facts and facts alone, so be it. But if Parliament confers on the tribunal the power to decide questions of law, that power must, in the absence of counter-indications, be taken to extend to the Charter, and to the question of whether the Charter renders portions of its enabling statute unconstitutional.
\end{abstract}

While she agreed that the enabling legislation did not expressly delegate the power to decide questions of law, McLachlin J canvassed the diverse functions spelled out in the Human Rights Act. Those functions, which included responsibility for handling complaints and reviewing Parliamentary regulations regarding human rights, suggested that the Commission must have the ability to interpret the law and was not "simply a rubber stamp, created to apply cipher-like the instructions Parliament delivers from above." ${ }^{51}$

The stark differences in Cooper led the Court to revisit the topic in Nova Scotia (Workers' Compensation Board) $v$ Martin. ${ }^{52}$ But while the Court spoke with one voice in Martin, the consensus was achieved by straddling the conflicting opinions in Cooper instead of coalescing around either formalist or democratic constitutionalism. From McLachlin J's opinion in Cooper, Gonthier J borrowed three related ideas. First, he noted that "the question of constitutional validity inheres in every legislative enactment" by virtue of s 52(1), which means that "every branch of government, including the administrative organs of the state" has a fundamental obligation to refuse to apply 
any law which conflicts with the Constitution. ${ }^{53}$ Second, he asserted that individuals should be able to assert their constitutional rights "in the most accessible forum available, without the need for parallel proceedings before the courts". ${ }^{54}$ Finally, he stated that "the factual findings and record compiled by an administrative tribunal, as well as its informed and expert view of the various issues raised by a constitutional challenge, will often be invaluable" when assessing whether the enabling legislation is constitutional. ${ }^{55}$

But Gonthier J supplemented these propositions by borrowing or building upon LaForest J's opinion in Cooper. He reiterated LaForest J's idea, first expressed in the trilogy, that administrative jurisdiction over Charter claims is ultimately contingent upon whether the legislature expressly or impliedly intended for administrative officials to determine questions of law. ${ }^{56}$ In the absence of an explicit delegation of power, implied jurisdiction could be ascertained through a holistic interpretation of the enabling legislation. For instance, if the tribunal's general statutory mandate required it to determine questions or law, or if the tribunal was "adjudicative" in nature, these factors might be sufficient to imply jurisdiction to apply the Charter. ${ }^{57}$ If the court concludes that administrative officials have been given express or implied jurisdiction to determine questions of law, a reviewing court should presume that those officials had jurisdiction to apply the Charter unless the presumption is "rebutted by an explicit withdrawal of authority to decide constitutional questions or by a clear implication to the same effect, arising from the statute itself." ${ }^{38}$ The Court deployed this same framework in $R v$ Conway to determine whether an administrative tribunal has jurisdiction to award a Charter remedy under s $24 .{ }^{59}$

The prescribed framework in Martin and Conway is problematic, because it hybridizes two conflicting perspectives regarding the constitutional status of administrative decision-makers. The first perspective, which harkens back to the preamble of the Constitution Act, 1867 and the pre-CUPE era of cases in Canadian administrative law, is premised upon "a Constitution similar in Principle to that of the United Kingdom"
- one in which Parliament is the supreme legislator, whose intent determines the parameters of administrative jurisdiction, including whether administrative officials are entitled to apply constitutional norms. The second perspective, which adopts s 52 of the Constitution Act, 1982 as its major premise, interprets the introduction of the Charter as signifying a transformation "from a system of Parliamentary supremacy to one of constitutional supremacy." ${ }^{60}$ This vision of Canadian constitutionalism envisions a more complex interaction or dialogue between legal institutions by asserting that all branches of government legislative, judicial, and executive - are co-ordinate interpreters of constitutional values. The problematic nature of the compromise struck in Martin is apparent in some awkward statutory provisions, like s 11 of the Alberta Administrative Procedures and Jurisdiction Act, which states that "a decision maker has no jurisdiction to determine a question of constitutional law unless a regulation...has conferred jurisdiction on that decision maker to do so." ${ }^{61}$ This raises an important question: how can one reconcile a statutory provision which directs administrative officials to ignore the Charter with s 52 of the Constitution Act, 1982, which states that the Constitution is the supreme law of Canada?

\section{Doré and the rise of reasonableness review}

This background helps to explain why the Court's decision in Doré is an unexpected, but welcome departure from established patterns in juridical thinking regarding the interplay between administrative law principles and the Charter. The Court's conclusion in Doré that administrative decisions which implicate Charter rights should be subject to reasonableness review means that judges should exercise restraint when reviewing these types of decisions. This conclusion was surprising, not only because the Court has consistently held that constitutional issues should be reviewed on a correctness standard since the trilogy, ${ }^{62}$ but also because the Court expressly rejected this proposition only six years earlier in Multani $v$ Commission scolaire Marguerite-Bourgeoys. ${ }^{63}$ 
In Multani, the Court reviewed a decision by a regional school board which prohibited a student from wearing a kirpan, a religious symbol in the shape of a dagger, on school property. While school officials had previously reached an agreement with the student's parents to allow the student to wear his kirpan, subject to certain safety conditions, the school's governing board and (later) council of commissioners refused to ratify the agreement on the grounds that it violated the school's code of conduct provisions prohibiting weapons. At first instance, Grenier J declared the board's decision void, and authorized the student to wear his kirpan subject to conditions similar to those outlined in the original agreement. However, the Court of Appeal overturned Grenier J's decision, on the grounds that the council's decision was reasonable and therefore justifiable under $s 1$ of the Charter.

In her majority opinion, Charron J held that the Court of Appeal had erred in subjecting the council's decision to reasonableness review instead of the Oakes test. She stated that the reasonableness standard was not "relevant" because the claimant's Charter rights were at stake. ${ }^{64}$ More specifically, Charron J worried that the reasonableness standard would "reduce the fundamental rights and freedoms guaranteed by the Canadian Charter to mere administrative law principles or, at the very least, cause confusion between the two." ${ }^{65}$ In support of this argument, she cited Lamer J's opinion in Slaight Communications, saying that if the council's decision did not satisfy the three part test laid out in Oakes then one could conclude that the council had exceeded its jurisdiction. ${ }^{66}$ After examining the available evidence, Charron J concluded that the council's decision did not satisfy the minimal impairment branch of the Oakes analysis because it had failed to demonstrate that the safety objective necessitated a blanket prohibition.

While Abella and Deschamps JJ agreed that the commission's decision was not adequately justified, they stated that "the case is more appropriately decided by recourse to an administrative law review than to a constitutional law justification." ${ }^{67}$ While the Oakes test was appropriate for assessing "a norm of general application, such as a statute or regulation", it was "not easily transportable" to determining "the validity of an administrative body's decision, even on a human rights question." ${ }^{8}$ Furthermore, they cited Baker to demonstrate that the administrative law standard of reasonableness already requires administrative officials to demonstrate that their decisions accord with "the principles of administrative law, the fundamental values of Canadian society, and the principles of the Charter." ${ }^{69}$ Accordingly, they argued that the Court's analysis should focus more directly upon the quality of the commission's reasoning instead of asking itself whether the decision satisfied the three prongs of the Oakes test. The following passage summarizes their approach to reasonableness review: ${ }^{70}$

\section{In making its determinations, the school board must take all fundamental values into consideration, including not only security, but also freedom of religion and the right to equality. The prohibition on the wearing of a kirpan cannot be imposed without considering conditions that would interfere less with freedom of religion or the accommodation measure proposed by the father and the student. It merely applied the Code de vie literally. By disregarding the right to freedom of religion, and by invoking the safety of the school community without considering the possibility of a solution that posed little or no risk, the school board made an unreasonable decision.}

Thus, the problem with the council's decision was not that it had failed to identify the least invasive means for attaining its objective of ensuring the safety of other students and staff members. Rather, the council's decision was unreasonable because it failed to recognize that the student's Charter rights were in play and failed to explain why a less restrictive measure, such as the proposed accommodation agreement, was incompatible with the commission's objective.

In Doré, the Court unanimously endorsed the approach Deschamps and Abella JJ outlined in Multani. The case concerned a decision by the disciplinary committee of the Barreau du Quebec to suspend the license of a criminal defense lawyer, Gilles Doré, for twenty-one days. While 
representing a client on a bail application, Doré became the target of invectives unleashed by the presiding justice, Justice Boilard. At various points in the proceedings, including the formal decision, the judge referred to Doré and his legal submissions as insolent, impudent, hyperbolic, and totally ridiculous. After leaving the courtroom, Dore wrote a personal letter addressed to Boilard J, in which he stated "your propensity to use your court - where you lack the courage to hear opinions contrary to your own - to launch ugly, vulgar, and mean personal attacks...casts shame on you as a judge" ${ }^{71} \mathrm{He}$ also sent a copy of the letter to the Chief Justice of the Superior Court, requesting that he no longer be required to appear in front of Boilard J. Shortly after mailing the letter, Doré filed an official complaint with the Canadian Judicial Council; and when the Chief Justice received her copy of Dorés letter addressed to Boilard J, she sent a copy of it to the Syndic du Barreau - the disciplinary branch of the provincial law society. Eight months later, the Syndic filed a complaint against Doré, alleging that he had violated article 2.03 of the Code of ethics of advocates, which states that a lawyer's conduct "must bear the stamp of objectivity, moderation and dignity." ${ }^{2}$

At his disciplinary hearing, Doré argued that article 2.03 of the Code of ethics violated his freedom of expression under s 2(b) of the Charter. However, the disciplinary council rejected this argument stating that, while the Code did limit lawyers' freedom of expression, the limit was "entirely reasonable, even necessary, in the Canadian legal system, where lawyers and judges must work together in the interest of justice." ${ }^{\prime 3}$ Further support for this conclusion was drawn from the fact that Doré had voluntarily joined a profession which he knew was governed by rules of ethics which regulated speech. After commenting upon the seriousness of the offense and Dorés lack of remorse, the panel suspended his license for 21 days.

As the case wound its way up to the Supreme Court, there was clearly some confusion about the appropriate standard of review. When Doré appealed the Council's decision to the Tribunal des professions, he abandoned his frontal assault on the constitutionality of the Code of ethics and instead argued that the Council's decision infringed his Charter rights. While the Tribunal upheld the council's decision, it eschewed a formal application of the Oakes analysis saying that the principal issue was "one of proportionality or, more specifically, minimal limitation of the guaranteed right." ${ }^{\prime 4}$ On judicial review, Déziel J held that the Tribunal's reasoning was "unassailable", 75 even though it had not conducted a full-fledged s 1 analysis, because it had "implicitly" concluded that the decision was minimally intrusive and therefore justified in a free and democratic society. ${ }^{76}$ Finally, the Court of Appeal upheld the Council's decision after conducting a full $s 1$ analysis, saying that the decision was both "proportional"77 and "not...unreasonable."78

In her judgment for a majority of the Supreme Court, Abella J noted "[i]t goes without saying that administrative decision-makers must act consistently with the values underlying the grant of discretion, including Charter values." 79 The more difficult problem was to determine whether an administrative decision demonstrated adequate regard for Charter values like freedom of expression, a problem which stemmed back to the subtle disagreement between Lamer J and Dickson CJ in Slaight Communications. The first, and most obvious, candidate was the Oakes test preferred by Lamer J in Slaight. The second, less likely, candidate was the reasonableness standard first set out in CUPE, and subsequently elaborated in Baker and Dunsmuir.

As in Multani, Abella J asserted that, while the Oakes test is apt in cases which concern the constitutionality of legislation, it is ill-suited to judicial review of administrative decisions which aim to reconcile legislative policies with Charter values. In her view, some aspects of the Oakes analysis, such as the requirement under $\mathrm{s} 1$ that a limit be "prescribed by law", were "poorly suited to the review of discretionary decisions" ${ }^{80}$ But the nub of Abella J's rationale for favouring reasonableness review is that the traditional rationale for deference in administrative law cases applies with equal vigour in cases where administrative officials have to balance their policy objectives with constitutional values. Cases like Baker 
and Dunsmuir recognized that administrative officials "are both bound by fundamental values and empowered to adjudicate them", and that judicial deference was owed to these decisions "on the basis of legislative intent, respect for the specialized expertise of administrative decisionmakers, and recognition that courts do not have a monopoly on adjudication in the administrative state." ${ }^{\prime 1}$ These same considerations applied in the Charter domain, because administrative officials have a "distinct advantage...in applying the Charter to a specific set of facts and in the context of their enabling legislation." ${ }^{2}$ The alternative of subjecting administrative decisions to correctness review based on de novo application of the Oakes test would overlook a valuable source of thought and experience about how the balance between the rule of law and social policy should be struck. ${ }^{83}$

While Abella J extended the reasonableness standard, she also provided administrative decision-makers with some guidance on how to engage in Charter analysis. She noted that decision-makers should first consider the objectives of the enabling legislation and "ask how the Charter value at issue will best be protected in view of the statutory objectives." ${ }^{44}$ Employing dicta from Dunsmuir, Abella J suggested that so long as the balance struck by the administrative decision-maker "falls within a range of possible, acceptable outcomes" a reviewing court should uphold the decision. ${ }^{85}$

However, when Abella J moved from articulating general principles to dealing with the specifics of the case under review, she seemed to gloss over important details in the Council's decision. She observed that the length of the suspension was not germane to the Court's assessment of the Disciplinary Council's decision, because Doré had already served the suspension and had not appealed the length of the penalty in the Court of Appeal. Thus, instead of asking specifically whether the penalty was proportionate or reasonable under the circumstances, she seemed to ask a more general question - whether there were reasonable, Charter compatible grounds, for sanctioning Dorés conduct. On this point, Abella J concluded that, because the Disciplin- ary Council recognized that there was a trade-off between a lawyer's right to express controversial (even provocative) views when defending a client and the profession's interest in preserving objectivity and decorum in judicial proceedings, the decision was not unreasonable. ${ }^{86}$

\section{Conclusion}

While the Supreme Court's decision in Doré might strike some as being unprecedented or provocative, the rationale for deference has deep roots in settled principles of Canadian administrative law. The idea that judges should defer to administrative decisions on the grounds of ensuring that justice is administered in an accessible, efficient, and contextually sensitive manner is hardly new, it just seems unorthodox in some cases because Canadian courts have traditionally claimed to have exclusive authority over constitutional values. Thus, Doré breaks new ground because it suggests that judges should respect the perspectives of administrative officials on such issues. ${ }^{87}$ But Doré also serves to focus the attention of both administrative officials and judges on the right sort of questions. Instead of suggesting that that there is one "correct" way to balance rights with public policy which can only be ascertained by judges, reasonableness review shifts the focus to asking whether an administrative official has provided an adequate justification for the outcome.

But this shift alone is not enough: in order to ensure that Charter values are not diminished or easily dismissed by administrative decisionmakers, reasonableness review should still be conceived in a relatively robust manner. One concern which Doré raises is that a conclusion will be ipso facto reasonable as long as administrative decision-makers formally acknowledge that policy objectives must be balanced against Charter values. Moreover, the Court's relatively terse assessment of the Disciplinary Council's decision in Doré is problematic - the Court does not inquire, for instance, whether the Council should have explained why less punitive measures (like a reprimand, fine, or shorter suspension) would not have struck an appropriate balance under the circumstances. Such an 
inquiry would not entail that the Court define the "correct" balance between policy objective of promoting professional civility and Dorés right of free speech, nor would it suggest that administrative decision-makers lack the ability to consider rights claims. Rather, it would ask whether the Council's reasons were adequate, in the sense that they demonstrate the gravity of the constitutionally significant questions posed by the case.

In this respect, the Court's reasoning in Doré should be supplemented by the underlying principles expressed in cases like Baker and Dunsmuir. If administrative decisions concerning Charter rights are sufficiently rigorous, in that their supporting rationales are transparent, intelligible, and justifiable as well as demonstrably "alert, alive, and sensitive" to the interests of claimants, then the decision would seem to be on solid footing. ${ }^{88}$ Further guidance might also be drawn from Abella J's analysis in Multani, a case in which she adopted a deferential standard of review, but nevertheless probed the school board's reasons to assess whether a blanket prohibition which prevented the claimant from bringing a kirpan to school even if it was safely secured was, in fact, reasonable under the circumstances. ${ }^{89}$

Finally, it is important to keep in mind that Doré is part of a larger swath of jurisprudence regarding the relationship between administrative law and the Charter. While the shift in Doré is encouraging, its rationale is out of step with the doctrinal frameworks which are applied when the issue is framed somewhat differently - as in cases where the issue is whether administrative officials can consider the constitutionality of their enabling legislation or whether they can grant Charter remedies under s 24. In these cases, the Charter's influence is constrained by the notion that administrative officials may only consult constitutional values when the legislature has specifically enabled them to determine questions of law. While this idea resonates with a formal account of the separation of powers that motivated much of Canadian public law prior to the emergence of the Charter, it conflicts with the notion that the Charter has transformed the Canadian legal system from one premised on
Parliamentary sovereignty to one founded on fundamental values. In order to unlock Dorés full potential to foster a more democratic discourse on constitutional values, the doctrinal approach to these related issues must be re-examined in future cases. ${ }^{90}$

\section{Notes}

* Associate Professor, Faculty of Law, University of Alberta.

1 Canadian Union of Public Employees, Local $963 v$ New Brunswick Liquor Corporation, [1979] 2 SCR 227, 97 DLR (3d) 417 [CUPE cited to SCR]. For the purposes of this paper, "administrative officials" refers to anyone exercising powers delegated by statute.

2 Madam Justice Claire L'Heureux-Dubé, "The "Ebb" and "Flow" of Administrative Law on the "General Question of Law"' in Michael Taggart, ed The Province of Administrative Law (Oxford: Hart Publishing, 1997) 308.

3 The latest spate of Supreme Court decisions confirm the trend toward a general standard of reasonableness review. See Matthew Lewans, "Deference and Reasonableness Review after Dunsmuir" (2012) 38:1 Queen's L J 59.

4 Doré v Barreau du Québec,2012 SCC 12, [2012] 1 SCR 395 [Doré].

5 David Dyzenhaus "Formalism's Hollow Victory" [2002] 4 NZL Rev 525.

6 See, eg the contrasting styles of reasoning employed by Kerwin J's concurring decision and Cartwright J's dissent in Toronto Newspaper Guild $v$ Globe Printing Company, [1953] 2 SCR 18, 1953 3 DLR 561.

7 Nicholson $v$ Haldimand-Norfolk (Regional) Police Commissioners [1979] 1 SCR 311, 88 DLR (3d) 671 [Nicholson cited to SCR].

8 CUPE, supra note 1.

9 Ibid at 230.

10 Ibid at 233.

11 Ibid at 235-236.

12 David Dyzenhaus \& Evan Fox-Decent "Rethinking the Process/Substance Distinction: Baker $v$ Canada" (2001) 51:3 UTLJ 193.

13 CUPE, supra note 1 at 237.

14 Baker $v$ Canada (Minister of Citizenship and Immigration), [1999] 2 SCR 817 at 855, 174 DLR (4th) 193.

15 Dunsmuir v New Brunswick, 2008 SCC 9 at para 47 [2008] 1 SCR 190. 
16 Kane $v$ Board of Governors of the University of British Columbia [1980] 1 SCR 1105 at 1112, [1980] 3 WWR 125.

17 Canada (AG) v Mossop, [1993] 1 SCR 554 at 585, 100 DLR (4th) 658 .

18 See, eg Canada (Canadian Human Rights Commission) $v$ Canada (AG), 2011 SCC 53, [2011] 3 SCR 471; British Columbia (Workers' Compensation Board) v Figliola, 2011 SCC 52, [2011] 3 SCR 422.

19 Slaight Communications Inc $v$ Davidson, [1989] 1 SCR 1038, DLR (4th) 416 [Slaight cited to SCR].

20 Ibid at 1078 (per Lamer J).

21 Ibid at 1076-1077.

22 Canada Labour Code, RSC 1985, L-2, s 242 (4) (c).

23 Slaight, supra note 19 at 1075.

24 Ibid at 1081.

25 Ibid at 1083.

26 Ibid at 1049.

27 Ibid.

28 Ibid at 1051.

29 Ibid at 1052.

30 Ibid at 1055-1056.

31 Douglas/Kwantlen Faculty Association v Douglas College, [1990] 3 SCR 570 , 77 DLR (4th) 94[Douglas/Kwantlen cited to SCR]; Cuddy Chicks Ltd v Ontario (Labour Relations Board), [1991] 2 SCR 5, 81 DLR (4th) 121 [Cuddy Chicks cited to SCR]; Tétrault-Gadoury v Canada (EIC), [1991] 2 SCR 22, 81 DRL (4th) 358 [Tétrault-Gadoury cited to SCR].

32 Douglas/Kwantlen, supra note 31 at 594-595; Cuddy Chicks, supra note 31 at 13-16; TétraultGadoury, supra note 31 at 31-35.

33 Cuddy Chicks, supra note 31 at 17.

34 Douglas/Kwantlen, supra note 31 at 594-595. The Court later held in Weber $v$ Ontario Hydro, [1995] 2 SCR 929, 125 DLR (4th) 583 that an administrative tribunal could qualify as a court of competent jurisdiction, provided that it had been given jurisdiction over the parties, subject matter, and remedy being sought.

35 Constitution Act, 1982, s 52(1), being Schedule B to the Canada Act 1982 (UK), 1982, c 11.

36 Cuddy Chicks, supra note 31 at 20.

37 Ibid.

38 Cooper $v$ Canada (Human Rights Commission), [1996] 3 SCR 854, 140 DLR (4th) 193 [Cooper cited to SCR].

39 Canadian Human Rights Act, RSC 1985, c H-6, s 15(c).

40 Cooper, supra note 38 at $886-887$.

41 Ibid at 888.

42 Ibid at 890-893.
43 Mossop, supra note 17.

44 Cooper, supra note 38 at 871.

45 Ibid at 871.

46 Ibid at $877-880$.

47 Ibid at 873 .

48 Ibid [emphasis in original].

49 Ibid at 899.

50 Ibid at 899-900.

51 Ibid at 910.

52 Nova Scotia (Workers' Compensation Board) v Martin, 2003 SCC 54, [2003] 2 SCR 504 [Martin].

53 Ibid at para 28.

54 Ibid at para 29.

55 Ibid at para 30.

56 Ibid para 35.

57 Ibid at para 41.

58 Ibid at para 42.

$59 R v$ Conway, 2010 SCC 22, [2010] 1 SCR 765.

60 Reference re Secession of Quebec, [1998] 2 SCR 217 at $258,161 \operatorname{DLR}\left(4^{\text {th }}\right) 385$.

61 Administrative Procedures and Jurisdiction Act, RSA 2000, c A-3, s 11.

62 See, eg Dunsmuir, supra note 15 at para 58.

63 Multani $v$ Commission scolaire MargueriteBourgeoys, 2006 SCC 6, [2006] 1 SCR 256 [Multani].

64 Ibid at para 20.

65 Ibid at para 16.

66 Ibid at para 23.

67 Ibid at para. 85 .

68 Ibid.

69 Ibid at para 86 citing Baker, supra note 14 at para 56.

70 Multani, supra note 63 at para 99.

71 Doré, supra note 4 at para 10.

72 Code of ethics of advocates, RRQ 1981, c B-1, r 3, art 2.03 as repealed by OIC 351-2004, s 7, (2004) GOQ II, 1273.

73 Bernard c Doré, 2006 QC CDBQ 53416 (CanLII) at para 88 .

74 Doré c Avocats (Ordre professional des), 2007 QCTP 152 (CanLII) at para 69.

75 Doré c Tribunal des professions, 2008 QCCS 2450 (CanLII) at para 105.

76 Ibid at para 104.

77 Doré v Bernard, 2010 QCCA 24 at para 50, [2010] QJ no 88 at para 47.

78 Ibid at para 47.

79 Doré, supra note 4 at para 24.

80 Ibid at para 37.

81 Ibid at paras 29-30.

82 Ibid at para 48.

83 Ibid at para 34.

84 Ibid at para 56. 
85 Ibid.

86 Ibid at paras. 70-71.

87 Beth Bilson, "The Voice from the Trenches: Administrative Tribunals and the Interpretation of the Charter" (2006) 69:1 SaskL Rev3; David Mullan, "Administrative Tribunals and Judicial Review of Charter issues after Multani" (2006/2007) 21 NJCL 127; Geneviève Cartier, "The Baker Effect: A New Interface Between the Canadian Charter of Rights and Freedoms and Administrative Law - The case of Discretion" in David Dyzenhaus, ed, The Unity of Public Law (Oxford: Hart Publishing, 2004) 61 . But see Susan L Gratton, "Standing at the Divide: The Relationship Between Administrative Law and the Charter Post-Multani” (2008) 53:3 McGill LJ 477.

88 Mullan, supra note 87.

89 See supra notes 63-69 and accompanying text.

90 Evan Fox-Decent \&Alexander Pless, “The Charter and Administrative Law: Cross-Fertilization or Inconstancy" in Lorne Sossin \&Colleen Flood, eds, Administrative Law in Context, $2 \mathrm{~d}$ ed (Toronto: Emond Montgomery, 2013) 407. 
